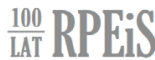

\author{
MARCIN WIŚNIEWSKI*, DOROTA WIŚNIEWSKA**, ADRIAN BECELLA***
}

\section{DETERMINANTY KREDYTU KUPIECKIEGO W POLSCE W ŚWIETLE WYNIKÓW ANALIZY DANYCH PANELOWYCH - CZYNNIKI ZRÓŻNICOWANIA WEWNĄTRZ- I MIĘDZYOBIEKTOWEGO}

\section{WPROWADZENIE}

Kredyt kupiecki jest jedną z najważniejszych form finansowania działalności operacyjnej przedsiębiorstw, której wykorzystanie nieustannie wzrasta. Istotą tego sposobu finansowania jest odroczenie przez dostawcę terminu płatności kupującemu w związku z realizowaniem pomiędzy podmiotami transakcji handlowych na rynku towarowym. Mając na uwadze rosnący udział kredytu kupieckiego w bilansach przedsiębiorstw w Polsce, zasadne staje się pytanie o przyczyny wzajemnego finansowania się partnerów handlowych.

Najnowsze badania prowadzone w kierunku identyfikacji determinant popytu na kredyt kupiecki w Polsce i jego podaży przeprowadził Adrian Becella ${ }^{1}$. Podjęte badania przeprowadzono z wykorzystaniem analizy danych panelowych, a otrzymane rezultaty pozwoliły wskazać istotne czynniki zmienności wewnątrzobiektowej podaży i popytu na tę formę finansowania.

W niniejszym opracowaniu autorzy kontynuuja, ale także modyfikują podjęte przez Becellę badanie, próbując odpowiedzieć na pytanie o determinanty (przyczyny) zróżnicowania międzyobiektowego popytu i podaży kredytu kupieckiego w Polsce, które przejawia się w istnieniu tzw. efektów indywidualnych modeli panelowych. Celem podjętego badania jest zatem ocena istotności wpływu wybranych czynników na wartości tych efektów. W szczególności au-

\footnotetext{
* Marcin Wiśniewski, Uniwersytet Ekonomiczny w Poznaniu, marcin.wisniewski@ue.poznan.pl, https://orcid.org/0000-0003-4609-6143

** Dorota Wiśniewska, Uniwersytet Ekonomiczny w Poznaniu, dorota.wisniewska@ue.poznan.pl,https://orcid.org/0000-0002-2584-9495

*** Adrian Becella, adrian.becella@interia.pl, https://orcid.org/0000-0003-3315-2134

1 Becella (2019).
} 
torzy mieli na celu sprawdzenie, czy słuszna jest wstępna hipoteza o tym, że zróżnicowanie międzyobiektowe badanego zjawiska jest kwestią branży.

W pierwszej kolejności zaprezentowano istotę kredytu kupieckiego i jego determinanty popytowe i podażowe wskazane w dotychczasowych badaniach. Następnie autorzy krótko przypomnieli zakres badania Becelli ${ }^{2}$, wskazując przy tym przyczynę i zakres proponowanych modyfikacji. Na koniec zaprezentowano wyniki przeprowadzonego badania przyczyn zróżnicowania międzyobiektowego.

\section{KREDYT KUPIECKI W DZIALALNOŚCI OPERACYJNEJ PRZEDSIĘBIORSTWA I CZYNNIKI DETERMINUJĄCE JEGO POPYT I PODAŻ}

W praktyce gospodarczej można wyróżnić wiele form finansowania przedsiębiorstw. Zasadniczo rozdziela się je na finansowanie zewnętrzne i wewnętrzne (w zależności od tego, czy kapitał zaangażowany w działalność pochodzi spoza przedsiębiorstwa, czy też powstaje w wyniku jego funkcjonowania) oraz finansowanie własne i obce (tj. kapitał pochodzący od właściciela przedsiębiorstwa lub jego wierzycieli). Kredyt kupiecki zalicza się do zewnętrznego finansowania za pomoca kapitału obcego, dokonującego się poprzez rynek towarowy ${ }^{3}$. Uznaje się go za pozabankową formę finansowania działalności przedsiębiorstw, która polega na odroczeniu przez dostawce płatności za sprzedaż towarów i usług odbiorcy ${ }^{4}$. Utożsamia się go również z pożyczka, udzielana odbiorcy za zakupione towary lub usługi, zatem forma finansowania, jaką oferuje dostawca na zakup swojego produktu ${ }^{5}$. Jego spłata nie jest wymagalna natychmiast ${ }^{6}$, ponieważ jej termin dostawca odracza na późniejszy okres w stosunku do daty sprzedaży ${ }^{7}$.

Odroczony termin płatności jest zatem częścią wspólną definicji kredytu kupieckiego rozmaitych autorów ${ }^{8}$. Opisywana forma finansowania jest z jednej strony utożsamiana z pozwoleniem dostawcy na opóźnienie zapłaty przez nabywcę ${ }^{9}$ z drugiej zaś - z obietnicą zapłaty w wyznaczonym terminie przez kupującego ${ }^{10}$. W różnych opracowaniach kredyt kupiecki określa się również mianem kredytu dostawcy lub kredytu odbiorcy, czy też kredytu handlowego ${ }^{11}$.

\footnotetext{
2 Becella (2019).

3 Podstawka (2017): 670-673.

4 Krzemińska (2005): 20-23.

${ }^{5}$ Chong, Yi (2011): 1.

${ }_{6}$ Brealey, Myers (1999): 1181.

7 Kubiak (2005): 32.

8 Biczyński, Miedziński (1991); Nowak (1996); Gęsicki, Gęsicki (1996).

9 Cuñat (2007): 491.

10 Adams, Wyatt, Kim (1992): 95.

11 Becella (2019): 21-29.
} 
Kredyt kupiecki zazwyczaj ma charakter krótkoterminowy, jednakże znaleźć można jego zastosowanie w finansowaniu średnio- i długoterminowym $^{12}$. Jego istota i cechy sprawiaja, że z łatwością zastępuje on inne źródła krótkoterminowego finansowania przedsiębiorstw, w tym bankowy kredyt obrotowy ${ }^{13}$. Uzyskiwane przez dostawców i nabywców korzyści ekonomiczne $\mathrm{w}$ transakcjach $\mathrm{z}$ odroczonym terminem płatności determinują nieustanny wzrost wolumenu transakcji handlowych finansowanych z jego udziałem. Atrakcyjność opisywanego instrumentu należy rozpatrywać przez pryzmat działalności zarówno kredytodawcy, jak również kredytobiorcy, różne są bowiem motywy jednych i drugich dla zawierania transakcji z odroczonym terminem płatności.

Korzyści odbiorcy towaru (kredytobiorcy, strony popytowej) przejawiaja się w uzyskaniu możliwości finansowania swojej działalności, a także zmniejszeniu kosztów jej prowadzenia, głównie w odniesieniu do kosztów transakcyjnych. Kredyt handlowy wpływa również na zmniejszenie ryzyka kupującego, za sprawą możliwości weryfikacji jakości produktu oraz samego dostawcy przed dokonaniem na jego rzecz zapłaty. We wskazanym ujęciu kredyt kupiecki z jednej strony pełni funkcję stymulującą działalność gospodarczą z drugiej zaś aktywizuje działania, zmierzające do minimalizacji ryzyka z nim związanego i wielkości ponoszonych kosztów. Takie podejście nawiązuje do klasycznego modelu kredytu kupieckiego związanego z podziałem czynników odbiorcy na transakcyjne i finansowe, wyrażonego przez Schwartza ${ }^{14}$, następnie rozwiniętego przez Smitha ${ }^{15}$ oraz Lee i Stowe'a ${ }^{16}$ w zakresie motywów weryfikacji jakości produktu, a także Summersa i Wilsona ${ }^{17}$ odnośnie do motywów finansowych odbiorcy i okoliczności operacyjnych.

Główną motywacją dostawców w zakresie składania oferty z opcją zapłaty w przyszłości (kredytodawcy, strona podażowa) jest wzrost realizowanego wolumenu sprzedaży. W literaturze wskazuje się na następujące motywy: marketingowy ${ }^{18}$, dyskryminacji cenowej ${ }^{19}$, ekonomii skali ${ }^{20}$ oraz czynników motywacyjnych, koordynacyjno-kontrolnych i informacyjnych ${ }^{21}$.

Szczegółowej prezentacji poszczególnych motywów oraz przeglądu badań w tym zakresie dokonał Becella ${ }^{22}$. Przeprowadził on również szczegółowa kwerendę badań pod kątem wykorzystywanych przez ich autorów zmiennych opisujących poszczególne motywy ${ }^{23}$. Analizowane badania prowadzone były dla

\footnotetext{
12 Łuczka (1998): 143.

13 Atanasova (2007): 49.

14 Schwartz (1974).

15 Smith (1987).

${ }^{16}$ Lee, Stowe (1993).

17 Summers, Wilson (1999).

18 Summers, Wilson (2003).

19 Schwartz, Whitcomb (1978).

20 Wilson, Summers (2002).

21 Mian, Smith (1992).

22 Becella (2019): 153-197.

${ }^{23}$ Becella (2019): 211-213, 228-229, 311-327.
} 
krajów innych niż Polska (z wyjątkiem badań Zawadzkiej² oraz Marzec i Pawłowskiej ${ }^{25}$ ), dlatego też, bazując na ich rezultatach, Becella przeprowadził aktualne badanie dla Polski. Badanie to stało się punktem wyjścia do podjętych w tym artykule analiz, stąd pokrótce zostanie ono opisane.

Zasadniczym celem badania było określenie istotności oraz kierunku i siły oddziaływania zmiennych determinujących popyt na kredyt kupiecki w Polsce i jego podaż. Badanie przeprowadzono na próbie 94 przedsiębiorstw działajacych nieprzerwanie i zarejestrowanych w Polsce od 2004 do 2015 r. Do obliczeń, z uwagi na niejednorodność badanych przedsiębiorstw, wykorzystano metodę analizy danych panelowych. Oszacowano dwa modele: model popytu na kredyt kupiecki i model podaży. Analogicznie do prowadzonych w historii badań przyjęto odpowiednio, że wielkość popytu stanowiły zobowiązania z tytułu dostaw towarów i usług, a wielkość podaży - należności z tytułu dostaw. Do szacowania wielkości popytu i podaży wykorzystano odpowiednio 13 i 8 potencjalnych zmiennych objaśniajacych, odpowiadających wyróżnionym wcześniej motywom, zidentyfikowanym na podstawie badań historycznych. Ich prezentacja zostanie dokonana w kolejnym punkcie, gdyż te same zmienne zostaną zastosowane $\mathrm{w}$ badaniu przedstawianym $\mathrm{w}$ niniejszym artykule.

Oszacowane modele wskazały na następujące prawidłowości:

- popyt na kredyt kupiecki zależy istotnie od: wartości zapasów (dodatnio), przychodów ze sprzedaży (dodatnio), wartości krótkoterminowych kredytów i pożyczek (ujemnie), odsetek od kredytów i pożyczek (ujemnie) i krótkoterminowych aktywów finansowych (ujemnie);

- podaż kredytu kupieckiego zależy w istotny sposób od: wzrostu przychodów ze sprzedaży z okresu na okres (dodatnio) i przychodów ze sprzedaży (dodatnio).

\section{CZYNNIKI WEWNĄTRZ- I MIĘDZYOBIEKTOWEGO ZRÓŻNICOWANIA POPYTU NA KREDYT KUPIECKI I JEGO PODAŻ - ZALOŻENIA BADAWCZE}

W przeprowadzonym badaniu założono, że istnieją uniwersalne czynniki, które wpływają na zmienność popytu (i podaży) na kredyt kupiecki w danym obiekcie (przedsiębiorstwie), przez co wartość zobowiązań (i należności) $\mathrm{z}$ tytułu dostaw zmieniają się $\mathrm{w}$ danym przedsiębiorstwie w czasie - czynniki te określono jako czynniki zmienności wewnątrzobiektowej. Dla przykładu popyt na kredyt kupiecki w danym przedsiębiorstwie może zmieniać się w odpowiedzi na zmiany oprocentowania kredytów bankowych, które stanowią alternatywna formę finansowania działalności przedsiębiorstwa. Jednocześnie mogą wystapić również czynniki specyficzne dla przed-

\footnotetext{
24 Zawadzka (2009).

25 Marzec, Pawłowska (2011).
} 
siębiorstw, które sprawiaja, że niezależnie od wartości czynników zmienności wewnątrzobiektowej, jedne przedsiębiorstwa wykazują ogólnie większa, a inne ogólnie mniejszą skłonność (lub predyspozycję) do stosowania „kredytu kupieckiego" - czynniki te określane będą mianem czynników zmienności międzyobiektowej. Dla przykładu, choć dwa przedsiębiorstwa mogłyby teoretycznie zaciagać podobnie oprocentowany kredyt bankowy, jedno z nich może mieć większa, a inne mniejszą skłonność do korzystania z tej formy finansowania. Wpływ obu rodzajów czynników schematycznie ma zilustrować wykres 1 .

\section{Wykres 1}

Ilustracja efektów wpływu czynników zmienności wewnątrzobiektowej i międzyobiektowej

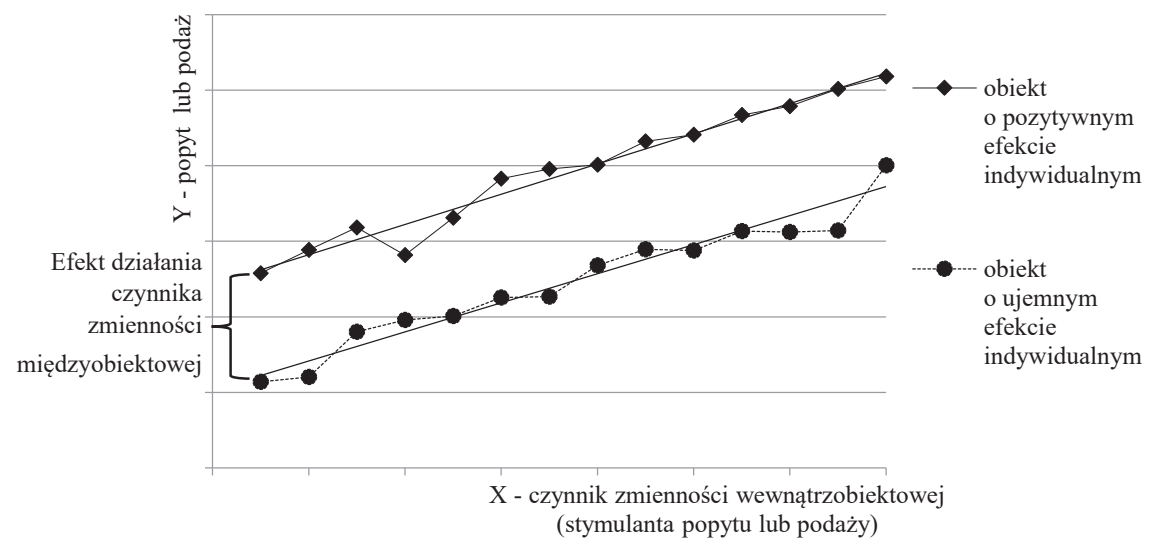

Źródło: opracowanie własne.

Aby możliwe było skwantyfikowanie wpływu obu rodzajów czynników, zdecydowano, że badania będa przeprowadzone na podstawie danych panelowych. Badaniem objęto 80 spółek akcyjnych notowanych na Giełdzie Papierów Wartościowych w Warszawie w okresie od 2004 do 2019 r., wcześniej badanych przez Becellę ${ }^{26}$. Liczbę badanych przedsiębiorstw w podziale na różnicujące je cechy (branżę i wielkość) zaprezentowano w tabeli 1. Niezależnie od tego, czy jako kryterium oceny wielkości przyjęte zostaną obroty, zatrudnienie czy suma bilansowa, nieco ponad połowa przedsiębiorstw byłaby sklasyfikowana jako przedsiębiorstwo duże. Dodatkowo nie było zależności między sektorem a wielkościa przedsiębiorstwa, co potwierdzały wyniki testu równości średnich wartości obrotów, zatrudnienia i sumy aktywów w poszczególnych sektorach (ANOVA i test Kruskala-Wallisa).

${ }^{26}$ Becella (2019). Z pierwotnej bazy usunięto kilka spółek o skrajnie nietypowych wartościach wskaźników. 
Tabela 1

Liczebność badanych przedsiębiorstw według branży i wielkości

\begin{tabular}{|l|c|c|c|c|c|}
\hline \multicolumn{1}{|c|}{ Sektor } & $\begin{array}{c}\text { Liczba } \\
\text { spółek }\end{array}$ & $\begin{array}{c}\text { Wielkość } \\
\text { firmy }\end{array}$ & $\begin{array}{c}\text { Według } \\
\text { wielkości } \\
\text { obrotów }\end{array}$ & $\begin{array}{c}\text { Według } \\
\text { zatrudnienia }\end{array}$ & $\begin{array}{c}\text { Według } \\
\text { sumy } \\
\text { aktywów }\end{array}$ \\
\hline Budownictwo & 12 & małe i mikro & 12 & 6 & 0 \\
\hline Przemysł & 39 & średnie & 27 & 19 & 28 \\
\hline Usługi & 29 & duże & 41 & 55 & 52 \\
\hline
\end{tabular}

Źródło: opracowanie własne.

Wartości zmiennych charakteryzujących te przedsiębiorstwa pozyskano z bazy Notoria Serwis S.A., uzupełniając występujące w niej braki bezpośrednio ze sprawozdań publikowanych przez spółki na stronach internetowych lub pozyskanych wprost od badanych spółek. Analizy przeprowadzono w programie Gretl i w programie SPSS.

Badanie podzielono na trzy główne etapy. W pierwszym etapie oszacowano parametry modelu danych panelowych opisującego kształtowanie się popytu na kredyt kupiecki (model popytu) i parametry modelu opisujaccego kształtowanie się podaży na kredyt kupiecki (model podaży). Aby możliwe było zrealizowanie celu głównego badania, zdecydowano się na zastosowanie modeli z ustalonymi efektami indywidualnymi. Ogólną postać oszacowanego modelu można zapisać następująco:

$$
Y_{i, t}=\alpha_{0}+\alpha_{i}+\alpha_{1} \cdot X 1_{i, t}+\cdots+\alpha_{k} \cdot X k_{i, t}+\varepsilon_{i, t},
$$

gdzie:

$i \quad-$ numer przedsiębiorstwa, $i=1,2, \ldots, 80$,

$t \quad-$ numer okresu, $t=1 \mathrm{w} 2004 \mathrm{r}$, $t=16 \mathrm{w} 2019 \mathrm{r}$.,

$\left(\alpha_{0}+\alpha_{i}\right)$ - wyraz wolny specyficzny dla $i$-tego przedsiębiorstwa; przy czym $\alpha_{0}$ to średni wyraz wolny, z kolei $\alpha_{i}$ wyraża efekt indywidualny $i$-tego przedsiębiorstwa (i zależnie od znaku wskazuje na relatywnie wyższą lub niższą skłonność do korzystania z kredytu kupieckiego),

$\alpha_{1}, \ldots, \alpha_{k}-$ współczynniki kierunkowe, wyrażające wpływ kolejnych czynników zmienności wewnątrzobiektowej,

$X k_{i, t} \quad$ - wartość $k$-tej zmiennej objaśniającej (czynnika zmienności wewnątrzobiektowej) dla $i$-tego przedsiębiorstwa w $t$-tym okresie,

$Y_{i, t} \quad-$ wartość zmiennej objaśnianej (miernik popytu lub podaży kredytu kupieckiego) dla $i$-tego przedsiębiorstwa w $t$-tym okresie,

$\varepsilon_{i, t} \quad-$ czynnik losowy związany z $i$-tym przedsiębiorstwem $\mathrm{w} t$-tym okresie, co do którego stosuje się założenia klasycznej regresji liniowej.

Przy wyborze zmiennych objaśniających kierowano się przede wszystkim pracą Becelli, w której pokazano, że wybrane zmienne są uznawane za czynniki 
opisujące motywy popytu lub podaży w literaturze przedmiotu oraz w której przedstawiono szerokie rozważania dotyczące oczekiwanego kierunku wpływu wybranych zmiennych ${ }^{27}$. Postanowiono jednak zastosować kilka ważnych modyfikacji. Po pierwsze (i najważniejsze), w badaniu Becelli za zmienne objaśniane przyjęto wartość zobowiązań z tytułu dostaw (w modelu popytu) i wartość należności z tytułu dostaw (w modelu podaży). W efekcie wstępne badania nad determinantami efektów indywidualnych doprowadziły do oczywistych wniosków, że efekty te można wyjaśnić najogólniej wielkością przedsiębiorstwa. Im wyższa była suma bilansowa, wielkość obrotów, czy nawet zatrudnienie, tym wyższe były wartości efektów indywidualnych, a zatem wyższy był również oczekiwany poziom zobowiązań i należności z tytułu dostaw. Mierniki wielkości (skali) przedsiębiorstwa wyjaśniały ponad 70\% zmienności efektów indywidualnych. Ten wstępny wynik skłonił autorów do przeprowadzenia badania, w którym rolę zmiennych objaśnianych w szacowanych modelach podaży i popytu $\left(Y_{i, t}\right)$ będą pełnić wskaźniki wyrażające relację wartości zobowiązań z tytułu dostaw do sumy bilansowej (w modelu popytu) i relację należności z tytułu dostaw do sumy bilansowej (w modelu podaży). Podobnego zabiegu dokonano w przypadku zmiennych objaśniajacych związanych z pozycjami bilansu, tak by wszystkie zmienne były wskaźnikami opisującymi strukturę bilansu.

\section{Tabela 2}

Zmienne przyjęte w modelach popytu i podaży kredytu kupieckiego na tle zmiennych w badaniu Becelli

\begin{tabular}{|c|c|c|}
\hline $\begin{array}{l}\text { Oznaczenie } \\
\text { zmiennej }\end{array}$ & $\begin{array}{c}\text { Wskaźnik w badaniu Becelli } \\
\text { (2019) }\end{array}$ & $\begin{array}{c}\text { Wskaźnik } \\
\text { w obecnym badaniu }\end{array}$ \\
\hline \multicolumn{3}{|c|}{ Model popytu na kredyt kupiecki } \\
\hline Popyt & $\begin{array}{l}\text { wartość zobowiązań z tytułu dostaw } \\
\text { towarów i usług }\end{array}$ & $\begin{array}{l}\text { wartość zobowiazań z tytułu dostaw } \\
\text { towarów i usług/ suma bilansowa }\end{array}$ \\
\hline Zapasy & wartość zapasów & wartość zapasów/ suma bilansowa \\
\hline Rot_Zapasów & $\begin{array}{l}\text { (wartość zapasów/ wartość sprzeda- } \\
\text { ży) } x \text { liczba dni w okresie }\end{array}$ & bez zmian \\
\hline Sprzedaż & przychody ze sprzedaży & $\begin{array}{l}\text { przychody ze sprzedaży/ suma } \\
\text { bilansowa }\end{array}$ \\
\hline Quick_Ratio & $\begin{array}{l}\text { (aktywa bieżące - zapasy)/ zobowią- } \\
\text { zania bieżące }\end{array}$ & bez zmian \\
\hline Zadłużenie & zobowiązania/ kapitał własny & $\begin{array}{l}\text { z uwagi na występowanie ujemnych } \\
\text { kapitałów własnych przyjęto wskaź- } \\
\text { nik: (kapitał własny-zobowiązania)/ } \\
\text { kapitał własny }\end{array}$ \\
\hline Zyskowność & $\begin{array}{l}\text { (zysk netto/ przychody ze sprzedaży) } \\
x 100 \%\end{array}$ & bez zmian \\
\hline
\end{tabular}

${ }^{27}$ Becella (2019): 247-251. 
cd. tab. 2

\begin{tabular}{|c|c|c|}
\hline Dług_Bankowy & $\begin{array}{l}\text { wartość krótkoterminowych poży- } \\
\text { czek i kredytów }\end{array}$ & $\begin{array}{l}\text { wartość krótkoterminowych poży- } \\
\text { czek i kredytów/ suma bilansowa }\end{array}$ \\
\hline Wiek & wiek kupującego w latach & bez zmian \\
\hline Odsetki & $\begin{array}{l}\text { zapłacone odsetki od kredytów } \\
\text { i pożyczek }\end{array}$ & $\begin{array}{l}\text { zapłacone odsetki od kredytów i po- } \\
\text { życzek/wartość kredytów i pożyczek }\end{array}$ \\
\hline Aktywa_Fin & $\begin{array}{l}\text { krótkoterminowe aktywa finansowe } \\
\text { bez środków pieniężnych }\end{array}$ & $\begin{array}{l}\text { krótkoterminowe aktywa finanso- } \\
\text { we bez środków pieniężnych/ suma } \\
\text { bilansowa }\end{array}$ \\
\hline Inwestycje_Kr & inwestycje krótkoterminowe & $\begin{array}{l}\text { inwestycje krótkoterminowe/ suma } \\
\text { bilansowa }\end{array}$ \\
\hline Inwestycje_Dł & $\begin{array}{l}\text { nieruchomości, wartości niemate- } \\
\text { rialne i prawne, długoterminowe } \\
\text { aktywa finansowe, inne inwestycje }\end{array}$ & te same kategorie/ suma bilansowa \\
\hline $\begin{array}{l}\text { Cykl_Opera- } \\
\text { cyjny }\end{array}$ & $\begin{array}{l}\text { wskaźnik długości cyklu operacyjne- } \\
\text { go w dniach }\end{array}$ & bez zmian \\
\hline \multicolumn{3}{|c|}{ Model podaży kredytu kupieckiego } \\
\hline Podaż & $\begin{array}{l}\text { wartość należności z tytułu dostaw } \\
\text { towarów i usług }\end{array}$ & $\begin{array}{l}\text { wartość należności z tytułu dostaw } \\
\text { towarów i usług/ suma bilansowa }\end{array}$ \\
\hline$\Delta \_$Sprzedaż & $\begin{array}{l}\text { wzrost przychodów ze sprzedaży } \\
\text { w okresie } t \text { w porównaniu do } t-1\end{array}$ & $\begin{array}{l}\text { (wzrost przychodów ze sprzedaży } \\
\text { w okresie } t \text { w porównaniu do } t-1 \text { )/ } \\
\text { suma bilansowa w okresie } t\end{array}$ \\
\hline Current_Ratio & $\begin{array}{l}\text { aktywa bieżące/ zobowiązania } \\
\text { bieżące }\end{array}$ & bez zmian \\
\hline Marża & $\begin{array}{l}\text { (przychody ze sprzedaży - koszty } \\
\text { sprzedanych produktów, towarów } \\
\text { i materiałów)/ przychody } x 100 \%\end{array}$ & bez zmian \\
\hline Efektywn_Sprz & $\begin{array}{l}\text { (marża zysku br. ze sprzedaży/ dłu- } \\
\text { gość cyklu operacyjnego) } x 100\end{array}$ & bez zmian \\
\hline Sprzedaż & przychody ze sprzedaży & $\begin{array}{l}\text { przychody ze sprzedaży/ suma } \\
\text { bilansowa }\end{array}$ \\
\hline $\begin{array}{l}\text { Cash_Conv_ } \\
\text { Cycle }\end{array}$ & $\begin{array}{l}\text { cykl operacyjny w dniach - rotacja } \\
\text { zobowiązań w dniach }\end{array}$ & bez zmian \\
\hline Rot_Należności & $\begin{array}{l}\text { (przeciętne należności / sprzedaż } \\
\text { netto) } x \text { liczba dni w okresie }\end{array}$ & bez zmian \\
\hline $\begin{array}{l}\text { Ryzyko Ryn- } \\
\text { kowe }\end{array}$ & liczba bankructw przedsiębiorstw & bez zmian \\
\hline
\end{tabular}

Źródło: opracowanie własne na podstawie Becella (2019): 247-251.

Kolejna modyfikacja dotyczy zmiennej „Odsetki” (tabela 2). Uznano, że sama wartość odsetek zapłaconych (w ujęciu bezwzględnym) nie jest porównywalnym miernikiem kosztu kredytu bankowego. Dlatego ustalono i badano wskaźnik względny, czyli relację wielkości zapłaconych odsetek do wartości kredytów i pożyczek. Skorygowano również sposób ustalania miernika zadłużenia. Pierwotnie przyjęty wskaźnik (zadłużenie/ kapitał 
własny) nie mógł pełnić ani roli stymulanty, ani destymulanty, występowały bowiem przypadki, gdy kapitał własny był ujemny, a w konsekwencji wartość wskaźnika była wówczas bardzo niska, nawet przy bardzo wysokim poziomie zadłużenia. Ostateczny wykaz zmiennych obu modeli przedstawia tabela 2 .

W przypadku wszystkich modeli zastosowano regresję krokową wsteczną w celu eliminacji nieistotnych zmiennych, przy poziomie istotności 0,05. W przypadku gdy występowała autokorelacja składnika losowego, dodatkowo oszacowano również dynamiczny model danych panelowych ${ }^{28}$. Sprawdzono, czy rodzaj zastosowanego modelu wpływa na kształtowanie się efektów indywidualnych - obliczono korelację między wartościami efektów uzyskanymi z modeli zawierajacych wszystkie potencjalne regresory, $\mathrm{z}$ modeli zredukowanych (po eliminacji zmiennych nieistotnych), jak również z modeli dynamicznych.

W drugim etapie zgromadzono oszacowania efektów indywidualnych dla każdego z 80 przedsiębiorstw $\left(\widehat{\alpha_{l}}\right)$ i sprawdzono, że efekty te są istotne (test $F$ ).

W trzecim etapie podjęto próbę wyjaśnienia zmienności międzyobiektowej popytu i podaży na kredyt kupiecki, czyli próbę identyfikacji czynników wyjaśniajaccych wartość efektu indywidualnego. W szczególności,

a) oceniono wpływ sektora (branże w podziale na usługi, budownictwo i przemyst ${ }^{29}$,

b) oceniono wpływ wielkości przedsiębiorstwa (wielkości obrotów, zatrudnienia i sumy bilansowej) oraz jego „średniego wieku” w badanym okresie,

c) oceniono wpływ innych charakterystyk (wskaźników finansowych) przedsiębiorstw, przy czym rozpatrywano tylko te charakterystyki, które uznano za cechy względnie stałe (mało zmienne w czasie) - kryterium klasyfikacji wskaźników była niska średnia wartość współczynnika zmienności cechy (poniżej 0,35). Decyzja o zbadaniu wpływu tych wskaźników wynikała z faktu, że choć wskaźniki tego typu mogą nie wyjaśniać zmienności wewnątrzobiektowej (mogą być nieistotne w modelu danych panelowych), to jednak wciąż moga wyjaśnić zmienność międzyobiektową.

Aby ocenić istotność czynników zróżnicowania międzyobiektowego, zastosowano podejście statystyczne i ekonometryczne. W przypadku gdy rozważany czynnik był cechą jakościowa, zastosowano test ANOVA i jego nieparametryczny odpowiednik: test Kruskala-Wallisa. W przypadku oceny istotności czynników ilościowych zastosowano współczynnik korelacji (Pearsona i Spearmana). Podejście ekonometryczne miało na celu określenie stopnia wyjaśnienia zmienności międzyobiektowej i sprowadzało się do oszacowaniu modelu regresji, w którym to rolę zmiennej objaśnianej pełniły efekty indywidualne przedsiębiorstw, a rolę zmiennych objaśniających stanowiły charakterystyki ilościowe (średnia wartość obrotów, zatrudnienia, sumy aktywów i inne) oraz

${ }^{28}$ Taką metodę eliminacji autokorelacji zaproponowano w: Beck, Katz (1995) i stosowano np. w Kus (2012).

${ }^{29}$ Niestety bardziej szczegółowa analiza branżowa nie była możliwa ze względu na mała liczebność uzyskiwanych grup. 
zmienne binarne (reprezentujące branże). Średnie wartości zmiennych ustalano na podstawie danych z lat 2004-2019. Ogólną postać modelu można zapisać następująco:

$$
\begin{aligned}
\alpha_{i}=\beta_{0}+ & \beta_{1} \cdot \overline{\text { Obroty }}_{i}+\beta_{2} \cdot \overline{\text { Zatrudnienie }}_{i}+\beta_{3} \cdot \overline{\text { Suma_Blansowa }}_{i}+\sum \beta_{k} \cdot \overline{X k}_{i}+ \\
& +\beta_{O, P R Z E} \cdot Z_{\text {PRZEMYSt }}+\beta_{O, U S E} \cdot Z_{\text {USŁUGI }}+\beta_{O, B U D} \cdot Z_{\text {BUDOWNICTWO }}+\varepsilon_{i},
\end{aligned}
$$

gdzie:

$\beta \quad$ - współczynnik regresji, przy czym $\beta_{0}$ pełni rolę wyrazu wolnego,

Z - zmienna zero-jedynkowa przyjmująca wartość 1, jeżeli przedsiębiorstwo jest firmą określonej branży, i przyjmująca wartość $0 \mathrm{w}$ przeciwnej sytuacji,

$\overline{X k}_{i} \quad$ - średnia wartość innych wskaźników, które charakteryzowały się niską zmiennością w czasie.

\section{WYNIKI ESTYMACJI MODELI DANYCH PANELOWYCH DLA POPYTU I PODAŻY NA KREDYT KUPIECKI}

Najważniejsze charakterystyki oszacowanych modeli danych panelowych zestawiono w tabelach 3 i 4 . Analizując wyniki uzyskane na tym etapie badań, trzeba podkreślić, że zarówno w modelu popytu, jak i modelu podaży efekty indywidualne okazały się istotne - istnieją zatem przedsiębiorstwa, w których udział zobowiązań (lub należności) w sumie bilansowej można uznać za istotnie wyższy niż średnio, a także takie, w których ten udział jest istotnie niższy niż oczekiwany. Z naturalnych względów zróżnicowanie efektów indywidualnych (mierzone np. rozstępem) jest niższe w modelach dynamicznych, jednakże zbadano, że ranking przedsiębiorstw według wartości efektu nie zależy ani od rodzaju modelu (statyczny, czy dynamiczny), ani od tego, czy efekty te ustalono przed czy po eliminacji zmiennych nieistotnych. We wszystkich przypadkach wartości efektów były bardzo wysoko skorelowane.

Tabela 3

Wyniki estymacji modelu panelowego popytu na kredyt kupiecki

\begin{tabular}{|l|c|c|}
\hline \multicolumn{1}{|c|}{ Zmienna } & Współczynnik & $\begin{array}{c}\text { Współczynnik } \\
\text { (model dynamiczny) }\end{array}$ \\
\hline Popyt $(t-1)$ & - & $0,506713^{* * *}$ \\
\hline Wyraz wolny (średni) & $0,250947^{* * *}$ & $0,0721757^{* * *}$ \\
\hline Zapasy & $-0,0000956^{* * *}$ & dodatni, nieistotny \\
\hline Sprzedaż & $0,0340557^{* * *}$ & $0,0284059^{* * *}$ \\
\hline Odsetki & $0,0899387^{* * *}$ & $0,0457418^{* * *}$ \\
\hline
\end{tabular}




\begin{tabular}{|l|c|c|}
\hline Inwestycje_dł & $-0,228002^{* * *}$ & $-0,0732423^{* * *}$ \\
\hline Inwestycje_kr & $-0,159822^{* * *}$ & ujemny, nieistotny \\
\hline Lsdv r & 0,591069 & 0,7359 \\
\hline Within-R & 0,137133 & 0,3903 \\
\hline Stat Durbina-Watsona & 0,87077 & 1,8952 \\
\hline Test istotności efektów indywidualnych & $F=12,363$ & $F=2,703$ \\
& $p=0,000$ & $p=0,000$ \\
\hline Max efekt indywidualny & 0,46226 & 0,2768 \\
\hline Min efekt indywidualny & $-0,15655$ & $-0,06962$ \\
\hline Współczynnik korelacji między efektami uzyskanymi z modeli & 0,9432 \\
\hline
\end{tabular}

Źródło: opracowanie własne.

\section{Tabela 4}

Wyniki estymacji modelu panelowego podaży kredytu kupieckiego

\begin{tabular}{|l|c|c|}
\hline \multicolumn{1}{|c|}{ Zmienna } & Wspólczynnik & $\begin{array}{c}\text { Wspólczynnik } \\
\text { (model dynamiczny) }\end{array}$ \\
\hline Podaż $(t-1)$ & - & $0,440579^{* * *}$ \\
\hline Wyraz wolny (średni) & $0,0833033^{* * *}$ & $0,0476744^{* * *}$ \\
\hline Sprzedaż & $0,115331^{* * *}$ & $0,0625862^{* * *}$ \\
\hline Cash_conv_cycle & $0,000008^{* *}$ & dodatni, nieistotny \\
\hline Lsdv ${ }^{2}$ & 0,750097 & 0,810719 \\
\hline Within-R ${ }^{2}$ & 0,235524 & 0,37349 \\
\hline Stat Durbina-Watsona & 1,10357 & 1,9933 \\
\hline Test istotności efektów indywidualnych & $F=22,893$ & $F=3,69997$ \\
& $P=0,000$ & $p=0,000$ \\
\hline Max efekt indywidualny & 0,24834 & 0,143496 \\
\hline Min efekt indywidualny & $-0,18936$ & $-0,10589$ \\
\hline Współczynnik korelacji między efektami uzyskanymi z modeli & 0,98888 \\
\hline
\end{tabular}

Źródło: opracowanie własne.

O dużym znaczeniu efektów indywidualnych świadczy fakt, że we wszystkich modelach wyjaśniony procent zmienności ogólnej jest znacznie wyższy niż wyjaśniony procent zmienności wewnątrzobiektowej - a zatem relatywnie lepiej udaje się modelować niejednorodny w badanych przedsiębiorstwach ogólny poziom popytu i podaży kredytu kupieckiego, niż wyjaśnić zmienność popytu i podaży w danym przedsiębiorstwie obserwowaną w kolejnych latach. Wprawdzie wśród zastosowanych zmiennych objaśniających kilka okazuje się być statystycznie istotnymi, to jednak nie można ich uznać za silne determinanty zmian podaży i popytu (wyjaśniają poniżej 40\% wariancji wewnątrzobiektowej). Co więcej, współczynniki determinacji zaprezentowanych modeli 
są niższe niż te uzyskane w badaniu Becelli ${ }^{30}$. Wynika to $\mathrm{z}$ faktu, że zmienna objaśniana nie jest tym razem bezwzględny poziom zobowiązań handlowych (i należności), lecz ich udział w sumie bilansowej.

\section{WYNIKI BADANIA DETERMINANT EFEKTÓW INDYWIDUALNYCH POPYTU NA KREDYT KUPIECKI}

Najważniejsze charakterystyki efektów indywidualnych uzyskanych w modelach popytu na kredyt kupiecki w zależności od sektora zestawiono w tabeli 5 .

Tabela 5

Parametryczne i nieparametryczne charakterystyki popytowych efektów indywidualnych w zależności od sektora

\begin{tabular}{|l|c|c|c|c|c|c|}
\hline \multicolumn{1}{|c|}{ Sektor } & N & $\begin{array}{c}\text { Średnia } \\
\text { wartość } \\
\text { efektu } \\
\text { indywidu- } \\
\text { alnego }\end{array}$ & $\begin{array}{c}\text { Odchylenie } \\
\text { standardo- } \\
\text { we efektu }\end{array}$ & $\begin{array}{c}\text { Wspó1- } \\
\text { czynnik } \\
\text { asymetrii }\end{array}$ & $\begin{array}{c}\text { Wspó1- } \\
\text { czynnik } \\
\text { koncentra- } \\
\text { cji }\end{array}$ & $\begin{array}{c}\text { Srednia } \\
\text { ranga }\end{array}$ \\
\hline Przemysł & 39 & $-0,0326$ & 0,075 & 0,771 & 3,420 & 34,4 \\
\hline Usługi & 29 & $-0,0063$ & 0,114 & 2,77 & 12,779 & 38,9 \\
\hline Budownictwo & 12 & 0,12112 & 0,107 & 0,772 & 3,420 & 64,2 \\
\hline
\end{tabular}

Źródło: obliczenia własne

Okazuje się, że relatywnie najwyższy poziom popytu na kredyt kupiecki zaobserwowano w przedsiębiorstwach budowlanych - udział zobowiązań z tytułu kredytu kupieckiego w sumie bilansowej jest w tym sektorze wyższy od oczekiwanego przeciętnie o 12,112 punktów procentowych. Z kolei najniższy średni poziom efektu przy najwyższym odchyleniu standardowym zaobserwowano w przypadku przedsiębiorstw przemysłowych. Choć różnice między średnimi wartościami efektu w próbie wydają się mało spektakularne, to jednak są statystycznie istotne. Świadczy o tym wynik klasycznego testu ANOVA $(F(2 ; 77)=11,918 ; p=0,000)$. Wyniki analizy post hoc opartej na statystyce Tukeya wskazuja, że średnia wartość efektu dla branży budowlanej jest istotnie różna od średnich w obu pozostałych sektorach. Z kolei nie można stwierdzić istotnych różnic między sektorami usług i przemysłu. Wyniki weryfikacji założeń testu ANOVA wskazały, że nie uzyskano podstaw do odrzucenia założenia o jednorodności wariancji, ale rozkład efektów w sektorze usługowym różni się

30 Becella (2019). 
istotnie od rozkładu normalnego ${ }^{31}$. Z tego względu dodatkowo przeprowadzono test nieparametryczny Kruskala-Wallisa. Wyniki testu $(H=15,280 ; p=0,000)$ doprowadzaja jednak do tych samych wniosków w zakresie zależności efektu od sektora, co test parametryczny.

Wyniki analizy korelacji między wartościami efektów indywidualnych a średnimi wartościami ilościowych charakterystyk spółek zestawiono w tabeli 6 . Oprócz wartości współczynnika korelacji liniowej Pearsona podano również wartości miernika korelacji rang Spearmana. Uzupełniająca analiza danych pozwoliła bowiem wysunać przypuszczenie, że mierniki Pearsona moga być zniekształcone na skutek występowania obserwacji odstających (przykładowo, wykres 3 ilustruje zależność efektu indywidualnego od średniej wartości wskaźnika rotacji należności: wyraźnie odstaje punkt charakteryzujący Stalexport Autostrady SA).

\section{Tabela 6}

Wyniki analizy korelacji między efektami indywidualnymi popytu na kredyt kupiecki a ilościowymi charakterystykami spółek

\begin{tabular}{|l|c|c|c|c|}
\hline \multicolumn{1}{|c|}{$\begin{array}{c}\text { Cecha } \\
\text { Przedsiębiorstwa }\end{array}$} & $\begin{array}{c}\text { Współczyn- } \\
\text { nik korelacji } \\
\text { Pearsona }\end{array}$ & Wartość $\boldsymbol{p}$ & $\begin{array}{c}\text { Współczyn- } \\
\text { nik korelacji } \\
\text { Spearmana }\end{array}$ & Wartość $\boldsymbol{p}$ \\
\hline Obroty & 0,009 & 0,934 & 0,049 & 0,667 \\
\hline Zatrudnienie & $-0,042$ & 0,708 & $-0,038$ & 0,739 \\
\hline Suma Bilansowa & $-0,018$ & 0,877 & $-0,006$ & 0,955 \\
\hline Wiek & 0,125 & 0,27 & 0,046 & 0,687 \\
\hline Cykl Operacyjny & 0,162 & 0,152 & 0,147 & 0,193 \\
\hline Rot_Należności & 0,11 & 0,329 & $\mathbf{0 , 3 5 8}$ & $\mathbf{0 , 0 0 1}$ \\
\hline Current_Ratio & $-0,037$ & 0,742 & $-\mathbf{0 , 3 0 2}$ & $\mathbf{0 , 0 0 7}$ \\
\hline Aktywa Obrot./ Ogółem & $\mathbf{0 , 3 9 0}$ & $\mathbf{0 , 0 0 0}$ & $\mathbf{0 , 3 6 8}$ & $\mathbf{0 , 0 0 1}$ \\
\hline
\end{tabular}

Źródło: obliczenia własne.

Wyniki analizy korelacji wskazują na istotna statystycznie, ale niezbyt silną pozytywną zależność między wartościami efektów indywidualnych a średnim poziomem udziału aktywów obrotowych w aktywach ogółem (ilustruje ja wykres 2). Jednocześnie test ANOVA $(F=6,622, p=0,002)$ pokazał, że udział ten był w sektorze budowlanym istotnie wyższy (średnia: 0,608 ) niż w pozostałych branżach (średnia dla usług to 0,450 , a dla przemysłu to 0,403 ). Zatem dwa zidentyfikowane czynniki zmienności międzyobiektowej, sektor i udział aktywów obrotowych w sumie bilansowej) mogą mieć ze sobą związek.

31 Zastosowano test Shapiro-Wilka i Kołmogorowa-Smirnova. 


\section{Wykres 2}

Efekty indywidualne w modelu popytu na kredyt kupiecki w zależności od średniej wartości udziału aktywów obrotowych w aktywach ogółem

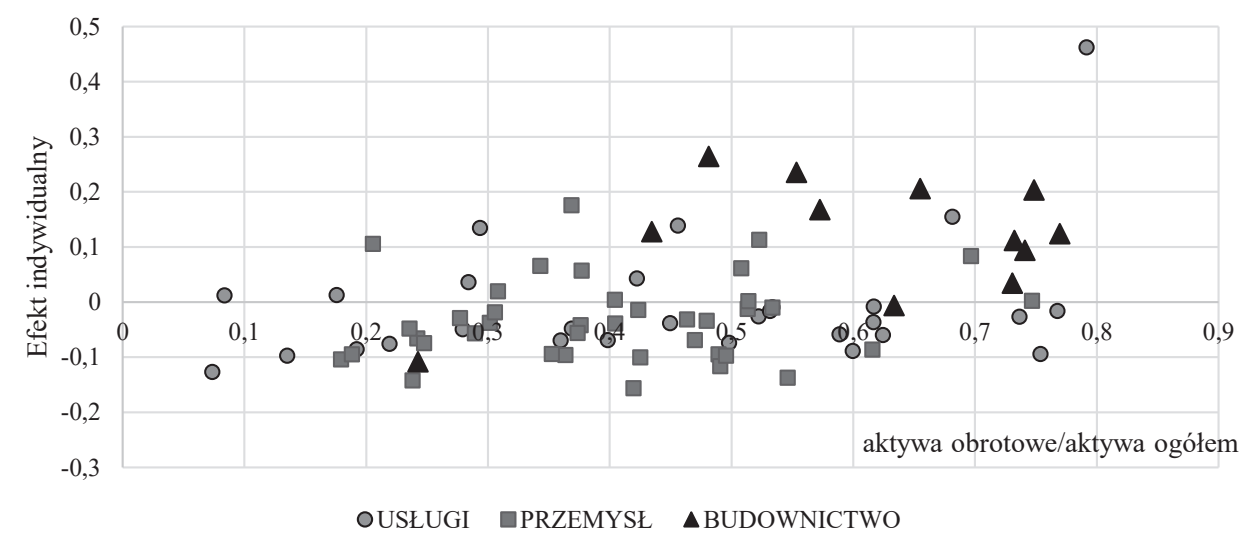

Źródło: obliczenia własne.

\section{Wykres 3}

Efekty indywidualne w modelu popytu na kredyt kupiecki w zależności od średniej wartości wskaźnika rotacji należności

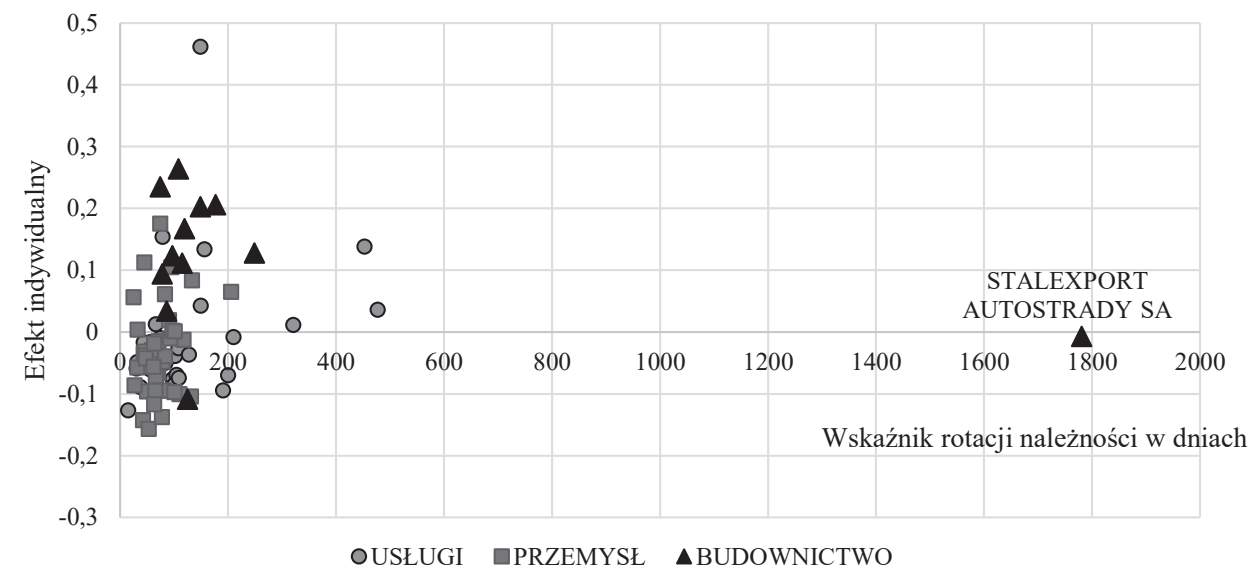

Źródło: opracowanie własne.

Współczynnik korelacji rang Spearmana wskazuje również na istotną zależność między efektami indywidualnymi a średnia wartościa wskaźnika rotacji należności i wskaźnika płynności bieżącej. Im dłużej przedsiębiorstwa muszą czekać na regulowanie należności przez kontrahentów, tym bardziej sa skłonne do korzystania z kredytu kupieckiego. Z kolei im wyższa jest płynność finansowa przedsiębiorstwa, tym niższa skłonność do wspomagania się kredytem kupieckim. 
Rezultaty uzyskane metodami statystycznymi zostały potwierdzone wynikami analizy regresji. Konstruując model efektów indywidualnych, przeprowadzono testy w celu identyfikacji obserwacji odstających i wpływowych. Taka obserwacją okazała się spółka wskazana na wykresie 3. Postanowiono zatem dodatkowo przedstawić wyniki estymacji modelu, uzyskane po wyłączeniu tej nietypowej obserwacji (tabela 7).

Tabela 7

Model regresji dla efektów indywidualnych w modelu popytu

\begin{tabular}{|l|c|c|c|c|}
\hline \multirow{2}{*}{ Zmienna objaśniająca } & \multicolumn{2}{|c|}{ Z obserwacją wplywową } & Bez obserwacji wpływowej \\
\cline { 2 - 5 } & $\begin{array}{c}\text { Współ- } \\
\text { czynnik }\end{array}$ & Wartość $\boldsymbol{p}$ & $\begin{array}{c}\text { Współ- } \\
\text { czynnik }\end{array}$ & Wartość $\boldsymbol{p}$ \\
\hline Wyraz wolny & $-0,1019$ & 0,0004 & $-0,1249$ & 0,001 \\
\hline Budownictwo (0-1) & 0,1066 & 0,0008 & 0,1148 & 0,0004 \\
\hline Rot_Należności (Dni) & 0,0004 & 0,0012 & 0,0004 & 0,0060 \\
\hline Aktywa Obrot./ Ogółem & 0,1561 & 0,0082 & 0,1616 & 0,0075 \\
\hline Current_Ratio & $-0,0139$ & 0,0003 & nieistotny & 0,0676 \\
\hline$R^{2}$ & \multicolumn{3}{|c|}{0,394} & \multicolumn{2}{|c|}{0,367} \\
\hline
\end{tabular}

Źródło: obliczenia własne.

Analizując oceny parametrów, warto podkreślić, że potwierdzają one wcześniejsze analizy korelacji. Udział zobowiązań z tytułu kredytu kupieckiego w sumie bilansowej może być ponadprzeciętny w przypadku przedsiębiorstw sektora budowlanego (w tym sektorze jest wyższy o nieco ponad 10 punktów procentowych niż w pozostałych sektorach). Dodatkowo udział ten jest wyższy w przedsiębiorstwach o relatywnie wyższych wartościach wskaźnika rotacji należności (w dniach) oraz o wyższym udziale aktywów obrotowych w aktywach ogółem. Możliwe jest też (choć wniosek ten nie jest pewny), że istnieje negatywna zależność między wartościami efektów indywidualnych a wskaźnikiem płynności firmy.

Wyodrębnione wskaźniki nie są jednak silnymi determinantami popytu na kredyt: nie wyjaśniają nawet 50\% zmienności efektów indywidualnych.

\section{WYNIKI BADANIA DETERMINANT EFEKTÓW INDYWIDUALNYCH PODAŻY KREDYTU KUPIECKIEGO}

Najważniejsze charakterystyki efektów indywidualnych uzyskanych w modelach podaży kredytu kupieckiego w zależności od sektora zestawiono w tabeli 8 . 


\section{Tabela 8}

Parametryczne i nieparametryczne charakterystyki podażowych efektów indywidualnych w zależności od sektora

\begin{tabular}{|l|c|c|c|c|c|c|}
\hline \multicolumn{1}{|c|}{ Sektor } & N & $\begin{array}{c}\text { Średnia } \\
\text { wartość } \\
\text { efektu } \\
\text { indywidu- } \\
\text { alnego }\end{array}$ & $\begin{array}{c}\text { Odchylenie } \\
\text { standardo- } \\
\text { we efektu }\end{array}$ & $\begin{array}{c}\text { Wspó1- } \\
\text { czynnik } \\
\text { asymetrii }\end{array}$ & $\begin{array}{c}\text { Wspó1- } \\
\text { czynnik } \\
\text { koncen- } \\
\text { tracji }\end{array}$ & $\begin{array}{c}\text { Średnia } \\
\text { ranga }\end{array}$ \\
\hline Przemysł & 39 & $-0,0247$ & 0,078 & 0,581 & 3,546 & 34,26 \\
\hline Usługi & 29 & $-0,0029$ & 0,083 & 0,822 & 3,699 & 40,31 \\
\hline Budownictwo & 12 & 0,0874 & 0,093 & 0,306 & 2,403 & 61,25 \\
\hline
\end{tabular}

Źródło: obliczenia własne.

Podobnie jak w przypadku zobowiązań, tak i w przypadku należności z tytułu kredytu kupieckiego najwyższą średnią wartością efektu indywidualnego modelu podaży uzyskano dla przedsiębiorstw budowlanych: udział należności handlowych w sumie bilansowej był w przypadku spółek tego sektora wyższy od oczekiwanego przeciętnie o 8,74 punktu procentowego. Z kolei najniższy średni poziom efektu zaobserwowano w przypadku przedsiębiorstw sektora przemysłowego. Dodatkowo rozkład efektów indywidualnych był zbliżony do rozkładu normalnego, wariancja efektów w grupach również zbliżona i nie uzyskano podstaw, by odrzucić założenia parametrycznego testu ANOVA. Wynik tego testu $(F(2 ; 77)=8,632 ; p=0,000)$ wskazuje, że wartości średnie efektów indywidualnych zależą od sektora. Z kolei wyniki analizy post hoc opartej na statystyce Tuckeya wskazuja, że w zakresie średniej wartości podażowych efektów indywidulanych nie ma istotnych różnic między sektorem usług i przedsiębiorstw. Od tych dwóch sektorów istotnie różni się jednak sektor budowlany.

Wyniki analizy korelacji między wartościami efektów indywidualnych modelu podaży na kredyt kupiecki a średnimi wartościami ilościowych charakterystyk spółek zestawiono w tabeli 9.

\section{Tabela 9}

Wyniki analizy korelacji między efektami indywidualnymi podaży kredytu kupieckiego a ilościowymi charakterystykami spółek

\begin{tabular}{|l|c|c|c|c|}
\hline $\begin{array}{c}\text { Cecha } \\
\text { Przedsiębiorstwa }\end{array}$ & $\begin{array}{c}\text { Współczyn- } \\
\text { nik korelacji } \\
\text { Pearsona }\end{array}$ & Wartość $\boldsymbol{p}$ & $\begin{array}{c}\text { Współczyn- } \\
\text { nik korelacji } \\
\text { Spearmana }\end{array}$ & Wartość $\boldsymbol{p}$ \\
\hline Obroty & $-0,207$ & 0,065 & $-0,182$ & 0,107 \\
\hline Zatrudnienie & $-0,183$ & 0,104 & $-0,138$ & 0,224 \\
\hline
\end{tabular}




\begin{tabular}{|l|r|r|r|r|}
\hline Suma Bilansowa & $\mathbf{- 0 , 2 5 1}$ & $\mathbf{0 , 0 4 4}$ & $\mathbf{- 0 , 2 9 4}$ & $\mathbf{0 , 0 0 8}$ \\
\hline Wiek & 0,075 & 0,506 & 0,105 & 0,355 \\
\hline Cykl Operacyjny & 0,001 & 0,990 & $\mathbf{0 , 3 1 4}$ & $\mathbf{0 , 0 0 5}$ \\
\hline Rot_Należności (dni) & 0,082 & 0,469 & $\mathbf{0 , 7 0 7}$ & $\mathbf{0 , 0 0 0}$ \\
\hline Current_Ratio & $-0,074$ & 0,512 & $-0,133$ & 0,239 \\
\hline Aktywa Obrotowe/ Ogółem & $\mathbf{0 , 5 3 1}$ & $\mathbf{0 , 0 0 0}$ & $\mathbf{0 , 5 0 3}$ & $\mathbf{0 , 0 0 0}$ \\
\hline
\end{tabular}

Źródło: obliczenia własne.

Ponownie zaobserwowano istotna statystycznie pozytywną zależność między wartością efektu indywidualnego a średnią wartością udziału aktywów obrotowych w aktywach ogółem. Ponadto można wnioskować o słabej, ale statystycznie istotnej negatywnej zależności między wartościami efektów indywidualnych a wielkością firmy mierzonej średnią wartością sumy bilansowej. Podobnie jak w przypadku analizy skłonności do zaciagania kredytu kupieckiego, również w tym przykładzie potwierdzono, że wartość współczynnika korelacji pozostała pod dużym wpływem wartości nietypowych (Stalexport Autostrady SA). Mniej wrażliwe na ich wpływ wartości współczynnika korelacji rang Spearmana wskazują na istotną negatywną zależność podażowych efektów indywidualnych i długości cyklu operacyjnego w dniach, przy czym zależność jest słaba. Wskazuja też na dosyć wyraźną pozytywną zależność z wskaźnikiem rotacji należności w dniach - w tym przypadku zależność łatwo uzasadnić: udzielenie kredytu kupieckiego wiąże się przecież z wydłużenie czasu na regulowanie należności z tytułu sprzedanych towarów i usług.

Wyniki pomiaru wpływu wszystkich rozważanych czynników zmienności międzyobiektowej prezentuje tabela 10 . Sa to wyniki estymacji końcowych modeli regresji opisujących kształtowanie się efektów indywidualnych w modelu podaży (przed i po usunięciu obserwacji nietypowej).

Tabela 10

Model regresji dla efektów indywidualnych w modelu podaży

\begin{tabular}{|l|c|c|c|c|}
\hline \multirow{2}{*}{ Zmienna objaśniająca } & \multicolumn{2}{|c|}{ Z obserwacją wpływową } & Bez obserwacji wpływowej \\
\cline { 2 - 5 } & Współczynnik & Wartość $p$ & Współczynnik & Wartość $p$ \\
\hline Wyraz Wolny & $-0,1068$ & 0,0000 & $-0,1648$ & 0,0000 \\
\hline Cykl Operacyjny (dni) & $<0$ & $>0,05$ & 0,0001 & 0,0010 \\
\hline Rot_Należności (dni) & $>0$ & $>0,05$ & 0,0007 & 0,0000 \\
\hline Aktywa Obrot./ Ogółem & 0,2159 & 0,0000 & 0,2417 & 0,0000 \\
\hline Budownictwo (0-1) & 0,0629 & 0,0132 & 0,0452 & 0,0490 \\
\hline $\mathrm{R}^{2}$ & \multicolumn{3}{|c|}{0,337} & \multicolumn{3}{c|}{0,537} \\
\hline
\end{tabular}

Źródło: obliczenia własne. 
Warto zauważyć, że choć współczynniki determinacji są wyższe niż w przypadku modelu opisującego popytowe efekty indywidualne, wciąż jednak nie udało się wyjaśnić dużego odsetka zmienności podażowych efektów. Z kolei zmienna zero-jedynkowa oznaczająca, że przedsiębiorstwo prowadzi działalność w sektorze budowlanym, jest zmienną na granicy istotności. Biorąc dodatkowo pod uwagę wartość oszacowanego współczynnika kierunkowego przy zmiennej zero-jedynkowej, można wnioskować, że fakt prowadzenia działalności budowlanej wyraźniej wpływa na skłonność do zaciagania kredytu kupieckiego niż do udzielania tego kredytu.

\section{PODSUMOWANIE}

Przedstawione wyniki badań pokazuja, że wielkość należności i zobowiązań z tytułu kredytu kupieckiego zależy nie tylko od czynników wpływających na ich zmienność w kolejnych latach funkcjonowania przedsiębiorstwa. Okazuje się, bowiem, że istnieje możliwość wskazania przedsiębiorstw, które (niezależnie od tego, czy w określonym okresie odnotowują spadek czy wzrost wartości tych zobowiązań lub należności) na tle innych przedsiębiorstw charakteryzuja się relatywnie wysokim (lub relatywnie niskim) poziomem tych charakterystyk.

Wyniki wstępnych badań pokazały, że ogólny poziom zobowiązań i należności z tytułu kredytu kupieckiego zależy przede wszystkim od wielkości przedsiębiorstwa, mierzonej wartością obrotów, zatrudnieniem lub sumą bilansową. Taka zależność wydała się wręcz oczywista, dlatego podjęto próbę wyjaśnienia tych kategorii w ujęciu względnym.

Przeprowadzone badania prowadzą do wniosku, że znacznie łatwiej skonstruować model empiryczny wyjaśniający wysoki odsetek zmienności popytu i podaży w ujęciu absolutnym niż w ujęciu względnym. Wszystkie zaprezentowane modele i metody badania zależności wskazuja, że choć można zidentyfikować charakterystyki przedsiębiorstw, które pozostają w statystycznie istotnej zależności z udziałem zobowiązań (należności) handlowych w sumie bilansowej, to jednak istniejące zależności nie sa silne. Nie zmienia to jednak faktu, że wyniki analizy danych panelowych wskazuja na istnienie popytowych i podażowych efektów indywidualnych: istnieja przedsiębiorstwa, których skłonność do zaciagania (lub udzielania) kredytu kupieckiego jest ponadprzeciętna, jak również istnieją przedsiębiorstwa, w których udział zobowiązań (należności) w sumie bilansowej jest poniżej oczekiwanych.

Czynnikiem, który jest pozytywnie skorelowany zarówno z podażowym, jak i popytowym efektem indywidualnym, jest średnia wartość wskaźnika rotacji należności w dniach. W przypadku efektu podażowego zależność wydaje się bardzo naturalna: wszelkie opóźnienia w dokonywaniu płatności przez kontrahentów przedsiębiorstw będą prowadziły do zwiększenia poziomu należności z tytułu sprzedanych wyrobów w bilansie przedsiębiorstwa, a jednocześnie udzielenie kredytu kupieckiego łączy się w wydłużeniem czasu spły- 
wania tych należności. Natomiast wpływ tego czynnika na efekty popytowe jest mniej oczywisty, ale dający się uzasadnić. Wszelki opóźnienia w odzyskiwaniu należności od kontrahentów moga powodować problemy z bieżącym regulowaniem własnych zobowiązań, a zatem mogą zwiększać skłonność do zaciagania kredytu kupieckiego.

Za interesujacy wniosek należy uznać zróżnicowanie sektorowe efektów indywidualnych, które wystapiło zarówno w przypadku popytowych, jak i podażowych efektów indywidualnych, lecz okazało się bardziej wyraźne w przypadku badania udziału zobowiązań z tytułu kredytu kupieckiego w sumie bilansowej. Wszystkie metody wskazuja, że udział ten jest istotnie wyższy niżby oczekiwano w przypadku, gdy przedsiębiorstwo prowadzi działalność budowlaną. Może mieć to związek z faktem, że - jak pokazały badania - sektor ten charakteryzuje się również istotnie wyższym udziałem aktywów obrotowych w aktywach ogółem, a na aktywa obrotowe składają się w tym przypadku magazynowane surowce, półfabrykaty, jak również mające dużą wartość produkty. Wydaje się również, że zwiększoną skłonność do zaciagania kredytu kupieckiego można także wiązać z długością procesu produkcyjnego w tym sektorze.

Adams, P.D., Wyatt, S.B., Kim, Y.H. (1992). A contingent claims analysis of trade credit. Financial Management 21(3): 95-103.

Atanasova, C. (2007). Access to Institutional Finance and the Use of Trade Credit. Financial Management 36(1): 49-67.

Becella, A. (2019). Kredyt kupiecki w Polsce - determinanty popytowe i podażowe. Warszawa: CeDeWu.

Beck, N., Katz, J. (1995). What to do and what not to do with time-series cross-section data. American Political Science Review 89: 634-647.

Biczyński, S., Miedziński, B. (red.) (1991). Słownik ekonomiki i organizacji przedsiębiorstwa. Warszawa: Państwowe Wydawnictwo Ekonomiczne.

Brealey, R.A., Myers, S.C. (1999). Podstawy finansów przedsiębiorstw. Tom 2. Warszawa: Wydawnictwo Naukowe PWN.

Chong, B., Yi, H. (2011). Bank loans, trade credits, and borrower characteristics: theory and empirical analysis. Asia-Pacific Journal of Financial Studies 40(1): 37-68.

Cuñat, V. (2007). Trade credit: suppliers as debt collectors and insurance providers. The Review of Financial Studies 20(2): 491-527.

Podstawka, M. (red.) (2017). Finanse. Instytucje, instrumenty, podmioty, rynki, regulacje. Warszawa: Wydawnictwo Naukowe PWN.

Gęsicki, Ł., Gęsicki, M. (red.) (1996). Słownik terminów ekonomiczno-prawnych. Łódź: Interfart.

Kus, B. (2012). Financialisation and income inequality in OECD nations: 1995-2007. The Economic and Social Review 43(4): 477-495.

Lee, Y.W., Stowe, J.D. (1993). Product risk, asymmetric information and trade credit. Journal of Financial and Quantitative Analysis 27(2): 285-300.

Łuczka, T. (1998). Kredyt od dostawcy jako źródło pozabankowego finansowania przedsiębiorstwa. Problemy ogólne. Ruch Prawniczy, Ekonomiczny i Socjologiczny 62(2): 143-157.

Marzec, J., Pawłowska, M. (2011). Racjonowanie kredytów a substytucja między kredytem kupieckim i bankowym - badania na przykładzie polskich przedsiębiorstw. Narodowy Bank Polski. Materiały i Studia 261.

Mian, S.L., Smith, C.W. (1992). Accounts receivable management policy: theory and evidence. The Journal of Finance 47(1): 169-200.

Nowak, E. (red.) (1996). Leksykon rachunkowości. Warszawa: Wydawnictwo Naukowe PWN. 
Schwartz, R.A. (1974). An economic model of trade credit. Journal of Financial and Quantitative Analysis 9(4): 643-657.

Schwartz, R.A., Whitcomb, D. (1978). Implicit transfers in the extension of trade credit, [w:] K.E. Boulding, T.F. Wilson, The Channels of Redistribution through the Financial System. Preager Special Studies. New York: 191-208.

Smith, J.K. (1987). Trade credit and information asymmetry. The Journal of Finance 42: 863-872.

Summers, B., Wilson, N. (1999). An empirical investigation of trade credit use. Credit Management Research Centre. Working Paper.

Summers, B., Wilson, N. (2002). An empirical investigation of trade credit demand. International Journal of the Economics of Business 8(2): 257-270.

Summers, B., Wilson, N. (2003). Trade credit and customers relationship. Managerial and Decision Economics 24(6/7): 439-455.

Zawadzka, D. (2009). Determinanty popytu małych przedsiębiorstw na kredyt handlowy. Identyfikacja i ocena. Poznań: Wydawnictwo Uniwersytetu Ekonomicznego w Poznaniu.

\section{TRADE CREDIT DETERMINANTS IN POLAND IN THE LIGHT \\ OF THE RESULTS OF PANEL DATA ANALYSIS: FACTORS \\ OF INTRA- AND INTER-OBJECT DIFFERENTIATION}

\section{Summary}

Trade credit is an important way of financing enterprises in Poland, yet it has also received little attention from researchers. In this article, the authors analyse what factors determine the choice of trade credit made by enterprises in Poland - as a source of financing and a form of receivables. In addition, the authors diagnose the existence of so-called individual effects that differentiate individual enterprises in terms of the general scale of trade credit application. The research conducted by the authors and described in this article indicates the relation between such effects and sector and asset structure.

Keywords: enterprise financing; trade credit; panel data analysis 